doi: 10.17492/pragati.v3i2.7742

\title{
Gender Perspective of Rural Livelihood and Household Income: Case Study of a Village in Odisha
}

\author{
Chittaranjan Nayak*
}

\begin{abstract}
A person's livelihood consists of her/his abilities, assets and activities required for a means of living. A gender analysis in the context of rural livelihood enables us to identify the different activities that men and women do. This paper intends to examine the role of gender in determining livelihood aspects like occupation structure and migration. It also investigates the role played by gender in determining employment, family income, and income distribution of individuals. The study is based on a census of 143 households of a village from the Bhadrak district of Odisha. The study observes significant gender gap in occupation structure, and income distribution across gender. If women are employed, household income increases significantly.
\end{abstract}

Keywords: Rural livelihood, Gender, Household income, Odisha.

\subsection{Introduction}

Women form about half of India's population, but their situation has been grim. For centuries, they have been deliberately denied opportunities of growth in the name of socio-cultural practices. Besides, the economic dependence, heavy domestic work-load which remained unpaid and unrecognized, absence of career and mobility, nonrecognition of their economic contribution, poor work conditions and wages, and monotonous jobs which men generally refused to do are still responsible for their disgraceful conditions. At the socio-political plain, women suffered from the denial of freedom even in their homes, repression and unnatural indoctrination, and unequal and inferior status. The condition of women is more despondent in rural India with respect to various socio-economic aspects. Although women have substantial contribution in household activities, they are never considered as "bread earners" like their male counterpart. This sense of women being inferior is passed on from generation to generation through psychological conditioning.

*Assistant Professor, Department of Economics, Ravenshaw University, Odisha. (email: chittaranjan.ru@gmail.com) 
The status of women is intimately connected with their economic status, which in turn, depends upon rights, roles and opportunity for the participation in economic activities. Mainstreaming a gender perspective depends on strengthening gendered access to sustainable livelihood. Realising this, the Government of India in 2015, under the DAY-NRLM ${ }^{1}$ has made provision for bringing at least one woman member from each identified rural poor household under the Self Help Group (SHG) network in a time bound manner. Special emphasis is particularly on the vulnerable communities. NRLM follows a demand driven strategy, the States have the flexibility to develop their livelihoods-based perspective plans and annual action plans for poverty reduction.

It is noteworthy that Odisha, which is considered as one of the poorest states, was the first state in the country to launch National Rural Livelihoods Mission (NRLM) in its bid to bring down rural poverty by promoting diversified and gainful selfemployment to the rural poor. In addition, the Government of Odisha has come out with a State Policy for Girls and Women in 2014 to ensure an enabling environment for equal opportunities. Central government as well as the state government do also run a good number of schemes like Mother and Child Tracking System, Indira Gandhi Matritva Sahyog Yojana, Conditional Maternity Benefit Plan, Rajiv Gandhi Scheme for Empowerment of Adolescent Girls- Sabla, Rashtriya Mahila Kosh, Mamata, etc. targeting weaker sections of women. In the existing welfare schemes also, women get certain extra attention. For example, the Mahatma Gandhi National Rural Employment Guarantee Act, 2005 guarantees 100 days of employment on a rural public works project to a member of rural households. The stipulation makes it mandatory that one third of the workers are women, which was not the case before. However, questions arise that, despite implementation of all such schemes, has the ground reality witnessed any transformation? Is there any gender parity in economic participation especially in rural areas, where women have been historically voiceless? An investigation on the crucial issue of gender aspect of livelihood is therefore imperative.

A person's livelihood is comprised of 'the capabilities, assets (material and social) and activities required for a means of living' (Chambers and Conway 1992). A gender analysis in the context of rural livelihoods enables us to identify the different activities that men and women do. An analysis as such can help ensure the provision of appropriate services that are needed by both men and women workers. It also facilitates us to look at how power relations within the household (normally seen as the private domain) interrelate with the wider public domain- the community, market and institutions of the State. In this backdrop, this paper intends to examine the role of gender in determining livelihood aspects like occupation structure and migration, and to 
investigate the role played by gender in determining employment, family income, and income distribution of individuals.

The following null hypotheses are tested in this paper.

H1. The occupation structure is independent of gender. In other words, there is no gender asymmetry in work participation in agriculture and non-farm activities.

$\mathrm{H} 2$. Migration is independent of gender. That is, men and women do migrate equally.

H3. The distribution of income is same across categories of gender.

H4. Gender related variables play no role in determining the family income.

The paper is organised as follows. Apart from the present section, Section 2 presents a review the relevant literature. Data and methods are outlined in Section 3. The results of the study are discussed in Section 4, and Section 5 summarises.

\subsection{Review of Literature}

Studies on gender and rural livelihood mainly focus either on the macro level policy and institutions or the micro level (household level) analyses. While there is increased data on women's condition, there is still a lack of data required for sophisticated analysis of the changes in gender relations within the household (Agarwal, 1994). Gathering and analysing gender disaggregated data provides quantitative and qualitative information on gender dynamics in development (DFID, 2009). Gender statistics and sex disaggregated data are the foundation of inclusive policy-making on rural development and agriculture because this type of data reveals critical disparities that would otherwise be overlooked (FAO, 2016).

Women's direct access to, and ownership of, land in India is affected by genderbiased inheritance laws, customary practices and land policies. Women mainly access and use agricultural land as sharecroppers, labourers, or de facto household heads due to male migration. In South Asia, about three to 10 per cent of the rural women own the land that they cultivate (Kelkar and Nathan, 2005). Direct access to land and formal rights are critical for female-headed households (headed by widows, abandoned and divorced women, or females becoming heads of household due to migration of the male head) to establish claims over household assets and labour contributions from immediate and extended.

Moreover, formal claims increase women's bargaining power within the household and increases household welfare (World Bank et al. 2008). An inverse relationship exists between women's property ownership and domestic violence against women (UNRISD, 2005). Livelihood strategies are influenced by 'access to and control over assets, access to markets, information and organization, effective management of 
vulnerability and the interaction of these policies at the global, national and local levels' (World Bank et al. 2008). A gender lens requires a focus on the following factors: a) assets (social, financial, human, physical, natural); b) markets; c) risk and vulnerability; and d) knowledge, information and organizations (ibid). This is a useful framework for incorporating gender.

There has also been focus on how migration affects household structure and the nature of the gender division of labour, etc. (Kabeer, 2007). The literature also illustrates that livelihood strategies include employment, but also incorporate informal sector employment, the use of common property resources, social networks, etc. At the household level, men and women have different access to and control over land, monetary resources, own labour and labour of other household members. All of these influence the choice of work, the nature of engagement at the market and at community levels. Regarding access to markets, men and women have different access to agricultural finance, input and produce markets because of gendered social norms, control over assets, and knowledge about market operations. Their access to and participation in labour markets is also different given the role they play within the household, social norms on mobility, gender segregation of occupation, etc.

In order to promote inclusion of women in mainstream development, improving legislative frameworks and institutional development to increase awareness on gender equality several measures have been taken in developing countries particularly in South Asian countries. However, majority of South Asian countries have not been able to add effective operational value to these policy initiatives and hence the ability of these initiatives to foster a sustainable structural transformation in favour of women is weaken (Kelker, 2005; Lopez and Zahidi, 2005; Islam and Haque 2007).

The gender dimensions of rural livelihoods across different regions are diverse and complex. It is difficult to draw conclusions about existing and emerging trends of gender dimension. On the one hand, they indicate that the established patterns of gender asymmetries regarding livelihoods are changing as more women enter agriculture labour markets and take up non-agriculture based work or diversify their livelihood strategies. They also indicate that new forms of gender asymmetries have emerged, which exist along with many of the older forms of gender asymmetries (Kabeer, 2007). There is also no established synchrony in micro and macro level studies. Insights from select rural areas which are very sluggish in responding to policy and regime changes are likely to throw some lights in this complex area of research. 


\subsection{Data and Methods}

The present study is based on primary data collected from a village during November-December 2015. The village Tentulia which is a medium size village in Bhandaripokhari block of Bhadrak district of Odisha was selected purposively. The village is situated at a distance of about 15 kilometres from the block headquarter Bhandaripokhari. Manjuri Road is the nearby market, which is located at a distance of about six kilometres from the village. It is considered as a backward village in terms of income and education. However, from general conversation with different people and institutions, and personal observations, a perception developed that this is a village where participation of women in socio-cultural activities is better in comparison to its neighbouring villages. Notwithstanding that economic participation is not visibly the same. This peculiarity in gender relation motivated us to take this village as a case study.

As per Census 2011, the village comprises 129 families with population 610 of which 310 are males while 300 are females. However, the number of households has increased to 143 in 2015 when survey for the present study was conducted. The study is done on the basis of census of all the households of the village. Data on different variables like livelihood, income, education, asset-base, etc. have been collected genderwise through a structured schedule-cum-questionnaire. A pilot survey was conducted to finalise the questionnaire and the enumerators were properly trained before going for the field survey.

The results are analysed through statistical tools like cross tabulations, nonparametric tests and regression analysis. Chi-square test and likelihood ratio test are used to examine $\mathrm{H}_{1}, \mathrm{H}_{2}$ and $\mathrm{H}_{3}$, whereas a multiple regression is attempted in order to test $\mathrm{H}_{4}$. The method of regression through backward elimination is used for selection of the variables. The final selection of the model was on the basis of adjusted $R^{2}$. Categorical regression is used to understand the relative importance of different gender related variables on per capita family income. The variables for the study are presented in Table 1. Per capita income has been considered as an outcome i.e. dependent variable, whereas all other variables are taken as independent variables.

The variables stated in Table 1are considered as the candidate variables. However, their final inclusion in the model is decided on the basis of regression through backward elimination. A linear multiple regression is attempted thereafter. The statistical software SPSS has been used for data analysis. 
Table 1: Variables of the Study

\begin{tabular}{|l|l|l|l|}
\hline $\begin{array}{l}\text { S. } \\
\text { No. }\end{array}$ & Abbreviation & Variable Name & \multicolumn{1}{|c|}{ Measurement and explanation } \\
\hline 1 & PCI & $\begin{array}{l}\text { Family Monthly Per } \\
\text { Capita Income }\end{array}$ & $\begin{array}{l}\text { Total income of all the family divided by the } \\
\text { family size }\end{array}$ \\
\hline 2 & FS & Family size & $\begin{array}{l}\text { The number of members in the family. It will } \\
\text { give some insights on relative productivity of } \\
\text { nuclear vis-a-vis joint family. }\end{array}$ \\
\hline 3 & GR & Gender Ratio & $\begin{array}{l}\text { The number of female members divided by } \\
\text { the number of male members. Higher gender } \\
\text { ratio may affect PCI if women are not } \\
\text { employed. }\end{array}$ \\
\hline 4 & AE & $\begin{array}{l}\text { Average Education } \\
\text { of the Family } \\
\text { Members }\end{array}$ & $\begin{array}{l}\text { Average years of schooling of household } \\
\text { members above fifteen years of age. The } \\
\text { study assumes that only these members } \\
\text { influence decision of the family. }\end{array}$ \\
\hline 5 & AA & $\begin{array}{l}\text { Average Age of } \\
\text { Family Members }\end{array}$ & $\begin{array}{l}\text { Summation of age of individual members } \\
\text { divided by the family size. Like GR, this may } \\
\text { also be taken as an indicator of dependency. }\end{array}$ \\
\hline 6 & MGN & Migration Status & $\begin{array}{l}\text { Migration takes place if residence changes. } \\
\text { The study has done multiple classification } \\
\text { regarding migration and commutation: 0-no } \\
\text { migration, 1-commuting within 20 kms, 2- } \\
\text { commuting above 20 kms, and 3-outmigration }\end{array}$ \\
\hline 7 & MGD & Migration Dummy & 1, if MGN=3, 0,otherwise \\
\hline 8 & WID & $\begin{array}{l}\text { Women Income } \\
\text { Dummy }\end{array}$ & $\begin{array}{l}\text { 1 if a woman has visible contribution to the } \\
\text { family income, otherwise zero. }\end{array}$ \\
\hline 9 & WED & $\begin{array}{l}\text { Women Education } \\
\text { Dummy }\end{array}$ & $\begin{array}{l}1, \text { if a woman is educated matriculation and } \\
\text { above, o-otherwise. }\end{array}$ \\
\hline
\end{tabular}

\subsection{Results and Discussion}

\subsection{Demographic and socioeconomic status}

According to Census 2011, the total geographical area of the village is 76 hectares. It had a total population of 610 people, out of which 310 were male and 300 female. However, as per census done by the present study in October 2015, total population has increased to 682, out of which 355 are male and 327 are female (Table 2). The total 
number of households has increased from 129 (Census 2011) to 143 as per this survey. The population in the age group 0-6 was 69 in 2011, which has decreased to 53 in 2015(Table 3, and Fig 1). This indicates that couples' adoption of voluntary family planning is on the rise. The child sex ratio ${ }^{2}$ has, however, increased from 81.58 to 96.3 during the period of comparison. Improvement in child sex ratio indicates reduction of biasness against girls. This is also evident from the survey area. In response to the question asked that, whether they will look for the third child since they are yet to be blessed with a son, at least two pairs of respondent couples categorically replied in the negative. Rising cost of rearing a child was cited as the most important reason for their family planning decision. However, some young couples shied away from this question. However, the sole bread-earner of a BPL family insisted to get a son even after the couple has already got five daughters.

Table 2: Population Composition of the Village

\begin{tabular}{|c|c|c|c|c|c|c|}
\hline \multirow{2}{*}{ Category } & \multicolumn{4}{|l|}{ As per Census 2011 } & As per this Survey \\
\cline { 2 - 7 } & Male & Female & Total & Male & Female & Total \\
\hline SC & 157 & 159 & 316 & 199 & 172 & 371 \\
\hline ST & 0 & 0 & 0 & 0 & 0 & 0 \\
\hline OBC & 153 & 141 & 294 & 128 & 123 & 251 \\
\hline GEN & 310 & 300 & 610 & 355 & 327 & 682 \\
\hline Total & & & & 28 & 32 & 60 \\
\hline
\end{tabular}
Source: Census 2011, and Primary data, 2015
Note: Census data does not enumerate OBC separately as done by this survey

The study observes that the child sex ratio of the Scheduled Caste people which was over 1000 in 2011, has fallen alarmingly to 864 much below the national and state figure. For the other categories, it has improved from 921 to 994. It is difficult to attempt any possible explanation within the framework of the present analysis. The analysis attempts for an age-sex decomposition of population of the village (Table 3). It is noticeable that about 67 percent people are in the age group 16 to 59 which is the major source of supply of labour force. However, it will be a major point to understand whether or not women who constitute about 48 percent of this age group are actually contributing to their family income.

As per Census 2011, the literacy rate of Tentulia village was $88.54 \%$ compared to $72.87 \%$ of Orissa. However, a more insightful attempt is made in this study to know what actually the average education of the family members is. The frequency distribution 
of average years of schooling of family members is presented in Figure 1. It seems to be a normal distribution with arithmetic mean around 8 . This means about 50 percent families have years of schooling below 8 .

Table 3: Age-Sex Composition of Population

\begin{tabular}{|l|c|c|c|}
\hline \multicolumn{1}{|c|}{ Sex } & Male & Female & Total \\
\hline $0-6$ & 27 & 26 & 53 \\
\hline $7-15$ & 56 & 48 & 104 \\
\hline $16-59$ & 240 & 219 & 459 \\
\hline 60 and above & 32 & 34 & 66 \\
\hline Total & 355 & 327 & 682 \\
\hline
\end{tabular}

Source: Authors' compilation from Primary Data

Fig. 1 Frequency Distribution of Average Years of Schooling

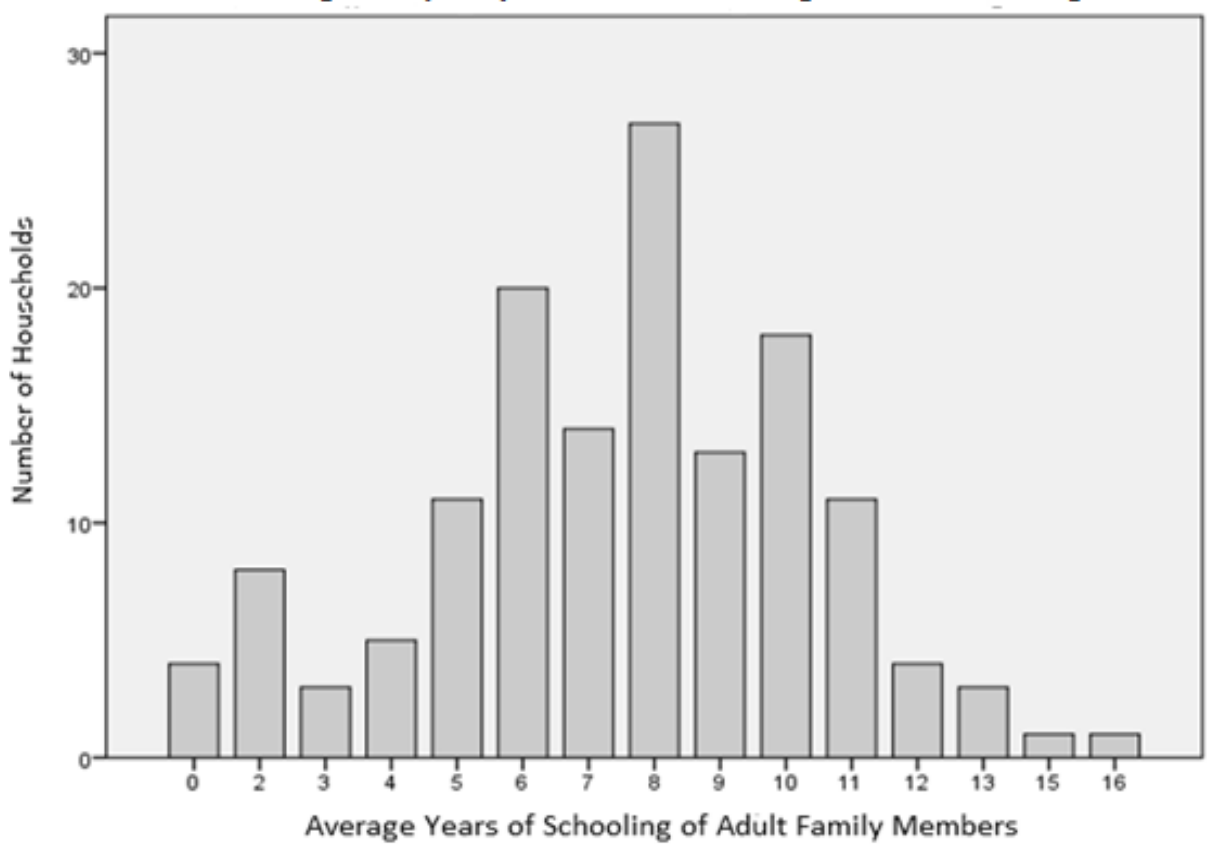

Out of 143 households surveyed, the study observed existence of only seven pucca (good) houses in the village, four out of which have been supported by Indira Awas Yojna. 13 houses were semi-pucca (semi permanent) and the rest of the houses were kutcha (thatched roof with mud base) houses. Only four households have latrine of 
any kind. The practice of open defecation is massive despite the fact that 73 percent households have at least one cell phone available in the family.

As regards drinking water, people basically use hand pump or tube well available either in their premises or arranged from neighbouring households. For fuel, most of the households depend on crop residues and cow-dung. Only one household had an LPG connection at home. There was not a single biogas connection to any household. But the picture was a bit encouraging regarding use of electricity. Almost all the houses, whether they are officially consumers or not, are availing electricity for lighting. But in response to the question whether they have electric fans at home, only 26 households said 'yes'. In the time of power cut, which is a regular phenomenon in the locality, they use kerosene lamps for lighting. Some households also use kerosene for fuel purposes in rainy days. Thirty one percent households in the surveyed village have Television at home but only eight households (about 5.6 percent of the total household) are owning a motored vehicle.

\subsection{Gender and rural livelihood}

At the outset the paper makes an effort to identify the sources of livelihood, and analyse the gendered access to and control over assets, which determine livelihood status in the study area. Surprisingly, not a single plot of land in the village is recorded in the name of a woman. This is a situation which is even worse than that is described by Agarwal (2003). However, there has been a spurt in the bank account which is basically motivated to get some benefits from government schemes. The analysis makes an attempt to examine the gender aspect of livelihood and how does it affect occupation structure, migration, and income of the household.

\section{Gender and Occupation Structure}

We have divided occupations into six different categories as follows:

a) Unemployed: Anybody in the age group 15-65 who likes to get an employment but has not availed it.

b) Farmers: Those whose substantive time, i.e. more than 50 percent of working hours is devoted for cultivation in own as well as hired-in land. The paper has also included all cultivators in this category.

c) Labourers: Basically this includes agricultural labourers who work in others' field.

d) Rural non-farm self-employed workers: This category includes rural small businesses and other forms of self-employment in nonfarm activities of the likes of insurance agents, artists, mechanics, contractors, blacksmiths, and so on. 
e) Private non-manual service holders: This includes non-manual jobs like private tuitions, carpentry, masonry, migrant workers in industries involving non-manual work etc. involving wage employment.

f) Government Servants: People engaged in regular or contractual government jobs. This category also includes retirement pensioners(not old-age pensioners).

Students in regular courses irrespective of age are excluded from labour force. However, the case of housewives is treated differently. In the absence of substantive land holding and livestock in the household, their main work is cooking and house-keeping. From an interaction with women in the study area, many of them revealed their preference for work since they have surplus time. Almost all of them like to contribute to the family income. Therefore they have been marked as unemployed.

The gender-wise classification of livelihood in the village is presented in Table 4. The study finds a staggering reality that as many as 96 percent of women are willing to work in some gainful sectors along with their housekeeping but they are unable to get any opportunity. Poverty, lack of access to institutional credit, and marketing risks were cited reasons for non-initiating a venture at home. On enquiry regarding the opportunity provided by MNREGA, some of the respondents said it is difficult to work too distant from home and that too for consecutive long hours.

Table 4: Gender-wise Occupation Structure

\begin{tabular}{|c|c|c|c|}
\hline \multirow{2}{*}{ Occupation } & \multicolumn{2}{|c|}{ Sex } & \multirow{2}{*}{ Total } \\
\cline { 2 - 3 } & Female & Male & \\
\hline Unemployed & 215 & 49 & 264 \\
\hline Farmers & 1 & 71 & 72 \\
\hline Labourers & 1 & 47 & 48 \\
\hline Business or Nonfarm employed & 0 & 17 & 17 \\
\hline Private Non-manual Service Holders & 4 & 47 & 51 \\
\hline Govt Servants or Pensioners & 1 & 3 & 4 \\
\hline Total & 222 & 234 & 456 \\
\hline
\end{tabular}

Source: Compiled from primary data with help of SPSS

In case of male population, 49 out of 234 male were unemployed. This population largely comprises youth who have just completed education or are out of education. It is noticeable from Table 4 that out of total 72 farmers, only one woman is a farmer. Similarly only one woman is doing labour work. It was quite insightful to know that despite poverty why don't women work as labourers? The family considers it as an 
ignominy if women are required to work in others' field. Rather they prefer to accept poverty. In the entire village, where the size of the labour force is 456 , only five people are either government servants or pensioners. Out of the two women, one in this category is actually a family pensioner. This means literacy rate is actually a deceitful indicator of education. Despite a very high percent of literacy ( 88 percent), just 2.5 percent of the work force of the village is employed in government job.

Figure 2 further explains the occupation structure caste category-wise for both the genders separately. The blue shading sub bars show the number of unemployed people. It seems women are unemployed irrespective of caste category. In case of male the highest number of people are engaged in agriculture either as farmers or as agricultural labourers. Out of 196 employed people, 100 people, basically men, are engaged in agriculture. 52 are farmers and 48 are labourers. Private non-manual job is also an important sector in the occupation structure of the village. A total of 51 workers i.e. about 26 percent workers in the village are in private non-manual job.

Figure 2: Gender-wise Occupation Structure of the village

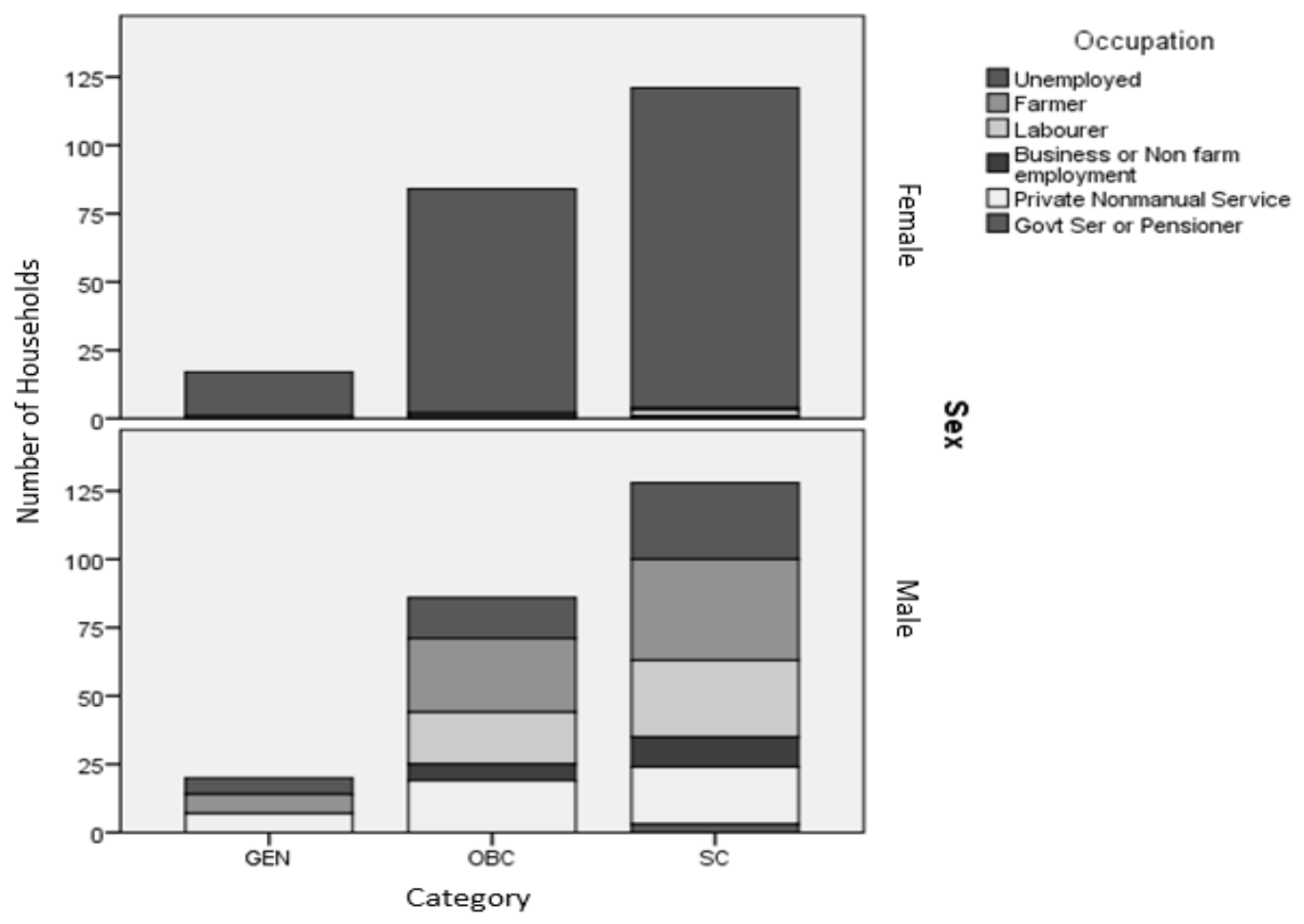


Test of $\mathbf{H}_{1}$ : Occupation structure is independent of gender.

The analysis has applied chi-square test, and likelihood ratio tests to verify $\mathrm{H}_{1}$, and the results are presented in Table 5.

Table 5: Chi-Square Test for $\mathrm{H}_{1}$

\begin{tabular}{|c|c|c|c|}
\hline & Value & df & $\begin{array}{c}\text { Asymp. Sig. (2- } \\
\text { sided) }\end{array}$ \\
\hline Pearson Chi-Square & 270.644 & 5 & .000 \\
\hline Likelihood Ratio & 325.705 & 5 & .000 \\
\hline N of Valid Cases & 456 & & \\
\hline Source: Primary Data
\end{tabular}

The p-values in both the tests confirm the decision in favour of rejecting $\mathrm{H}_{1}$. The finding is that the occupation structure is not independent of gender. Gender plays a role in livelihood. If the person is a woman, she is likely to be unemployed given the conditions of the surveyed village.

\section{Gender and Migration}

The gendered impact of migration is detailed in existing literature. The present study examines this issue by the individual level disaggregated data from the village Tentulia. The study could not find even one instance of out-migration of women (Table 6). There was only one case of 'commuting within $20 \mathrm{kms}$ ' of woman. So, migration in the village is absolutely a matter of interest for men only.

Table 6: Gender-wise Migration (persons)

\begin{tabular}{|c|c|c|c|c|}
\hline \multicolumn{2}{|c|}{} & \multicolumn{2}{|c|}{ Sex } & \multirow{2}{*}{ Total } \\
\cline { 3 - 5 } \multicolumn{2}{|c|}{} & Female & Male & \\
\hline \multirow{3}{*}{\begin{tabular}{l} 
Migration \\
\cline { 2 - 5 }
\end{tabular}} & 0 & 221 & 151 & 372 \\
\cline { 2 - 5 } & 1 & 1 & 38 & 39 \\
\cline { 2 - 5 } & 2 & 0 & 15 & 15 \\
\hline & 3 & 0 & 30 & 30 \\
\hline \multicolumn{2}{|c|}{ Total } & 222 & 234 & 456 \\
\hline
\end{tabular}

Source: Compiled from primary data

Notes: Migration: O-No migration, 1-Commuting within $20 \mathrm{kms}$, 2-Commuting beyond 20kms, 3-Out migration 
Test of $\mathbf{H}_{2}$ : Migration is independent of gender.

$\mathrm{H}_{2}$ is tested in similar way as $\mathrm{H}_{1}$. The analysis rejects $\mathrm{H}_{2}$ on the bases of Chi-square and likelihood ratio tests (Table 7). So gender plays an important role in migration which is considered as an important factor determining livelihood.

Table 7: Chi-Square Test for $\mathbf{H}_{2}$

\begin{tabular}{|c|c|c|c|}
\hline & Value & df & Asymp. Sig. (2-sided) \\
\hline Pearson Chi-Square & $93.023^{\mathrm{a}}$ & 3 & .000 \\
\hline Likelihood Ratio & 120.083 & 3 & .000 \\
\hline N of Valid Cases & 456 & & \\
\hline \multicolumn{2}{|l}{ a. 0 cells $(0.0 \%)$ have expected count less than 5. The minimum expected count is 7.30.} \\
\hline
\end{tabular}

\section{Gender and income distribution}

Income is an important indicator of livelihood status. The present study has gathered information on BPL and APL status of families as per official records. However, given the fact that household income is a pooled income of both men and women, it is difficult to reflect on gender relation by analysing income distribution of households. On the contrary we need disaggregated data on individual earning of family members. The study has attempted to make an analysis of the distribution of income across gender on the basis of individual level data.

Test of $\mathbf{H}_{3}$ : That, the distribution of income is same across categories of gender.

Quite similar to the way $\mathrm{H}_{1}$ and $\mathrm{H}_{2}$ tested, the null hypothesis $\mathrm{H}_{3}$ is also rejected on the basis of chi-square and likelihood ratio test. It is noticeable that the p-value, i.e. the exact level of significance is almost 0 for both the tests. This implies there is severe skewness in the distribution of income between men and women of the village. This conclusion is also corroborated by Mann-Whitney U test result.

Table 8: Chi-Square Test for $\mathrm{H}_{3}$

\begin{tabular}{|c|c|c|c|}
\hline & Value & df & Asymp. Sig. (2-sided) \\
\hline Pearson Chi-Square & $289.151^{\text {a }}$ & 33 & .000 \\
\hline Likelihood Ratio & 362.340 & 33 & .000 \\
\hline N of Valid Cases & 456 & & \\
\hline a. 55 cells $(80.9 \%)$ have expected count less than 5. The minimum expected count is 0.49. \\
\hline
\end{tabular}

If women work, they are likely to get some earning. In the surveyed village, apart from looking after the domestic cores, there was no instance of women working for any gainful employment. 


\subsection{Impact of gender-related variables on household income}

As described in Table 1, the study has considered Gender Ratio (GR), Family Size (FS), Average Education of Family Members (AE), Average Age of Family Members (AA), Migration (MGD) ${ }^{3}$, Women Education (WED), Women Income (WID) as exogenous variables influencing income of the family. The last three variables are taken as dummy variables, in which the presence of the character is marked as 1, otherwise 0. All these variables have gender connotations. Monthly Per Capita Income of the Household (PCI) is the dependent variable. However, the decision on inclusion of these variables is taken with help of the technique of regression through backward elimination as detailed below. The results of the regression through elimination are presented in Table 9.

Table 9: Model Summary of Backward Regression

\begin{tabular}{|c|c|c|c|c|c|}
\hline Model & $\mathbf{R}$ & R Square & $\begin{array}{c}\text { Adjusted R } \\
\text { Square }\end{array}$ & $\begin{array}{c}\text { Std. Error of } \\
\text { the Estimate }\end{array}$ & $\begin{array}{c}\text { Durbin- } \\
\text { Watson }\end{array}$ \\
\hline 1 & $.661^{\text {a }}$ & .437 & .407 & 823.518 & 1.854 \\
\hline $\mathbf{2}$ & $\mathbf{. 6 6 0}^{\mathbf{b}}$ & $\mathbf{. 4 3 6}$ & $\mathbf{. 4 1 1}$ & $\mathbf{8 2 1 . 3 8 0}$ & $\mathbf{1 . 8 6 3}$ \\
\hline 3 & $.654^{\mathrm{c}}$ & .428 & .407 & 823.928 & 1.867 \\
\hline 4 & $.647^{\mathrm{d}}$ & .418 & .401 & 827.931 & 1.894 \\
\hline 5 & $.640^{\mathrm{e}}$ & .409 & .396 & 831.230 & 1.874 \\
\hline
\end{tabular}

a. Predictors: (Constant), AE, MGD, FS, GR, WID, AA, WED

b. Predictors: (Constant), AE,MGD, GR, WID, AA, WED

c. Predictors: (Constant), AE, MGD, WID, AA, WED

d. Predictors: (Constant), MGD, WID, AA, WED

e. Predictors: (Constant), MGD, WID, WED

f. Dependent Variable: PCI

On the basis of the adjusted R-square as reflected in the technique of regression by backward elimination, the Model 2 is taken for the analysis. Consequently, average education of household, migration dummy, gender ratio, women income dummy, age of family members, and women education dummy are taken as the predictors for the dependent variable family monthly per capita income (PCI). The Durbin-Watson d-test confirms that there is no autocorrelation problem in the model. The model is also tested for possible multicollinearity. The TOL score confirms that multicollinearity is not actually a problem in this model. The R-square value of the final model shows that about 44 percent variation in income of households is explained by the six regressors 
collectively, which is significant at 1 percent level. The p-value of $F$, which is about 0 (Table 10). The regression coefficients are presented in Table 11.

Table 10: ANOVA Results

\begin{tabular}{|l|r|r|r|r|r|}
\hline & \multicolumn{1}{|c|}{ Sum of Squares } & \multicolumn{1}{c|}{ df } & Mean Square & \multicolumn{1}{l|}{ F } & \multicolumn{1}{l}{ Sig. } \\
\cline { 1 - 4 } Regression & 68362688.460 & 6 & 11393781.410 & \multirow{2}{*}{16.407} & \multirow{2}{*}{$.000^{\mathrm{b}}$} \\
\cline { 1 - 5 } Residual & 94446109.610 & 136 & 694456.688 & & \\
\hline Total & 162808798.070 & 142 & & & \\
\hline
\end{tabular}

Dependent Variable: FPCI

Predictors: (Constant), AE, MGD, GR, WID, AA, WED

Table 11: Regression Coefficients

\begin{tabular}{|c|r|r|c|c|}
\hline \multirow{2}{*}{ Regressor } & \multicolumn{2}{|c|}{ Unstandardized Coefficients } & \multirow{2}{*}{ T } & p-values \\
\cline { 2 - 3 } & \multicolumn{1}{|c|}{ B } & Std. Error & & \\
\hline (Constant) & 344.75 & 367.084 & .939 & .349 \\
\hline AA & 12.83 & 7.603 & 1.688 & .094 \\
\hline WID & 3164.05 & 444.720 & 7.115 & .000 \\
\hline GR & -1.14 & .839 & -1.358 & .177 \\
\hline MGD & 791.73 & 186.924 & 4.236 & .000 \\
\hline WED & 332.41 & 167.396 & 1.986 & .049 \\
\hline AE & 46.43 & 28.191 & 1.647 & .102 \\
\hline
\end{tabular}

Source: Analysed from Primary data

Test of $\mathbf{H}_{4}$ : Gender related variables play no role in determining the family income.

The overall impact is shown by the F-value stated in Table 10. The F-value is 16.407, which is highly significant. The impact of the individual variables on PCI is measured in Table 11. Except for the regression coefficient of PCI on GR, all other coefficients are positive. The coefficients in relation to women income(WID), women employment, and migration contributes significantly to monthly per capita household income. Thus the null hypothesis $\mathrm{H}_{4}$ is summarily rejected. The conclusion is that gender plays a significant role in raising per capita income of households. If women are educated, women start earning and they are not biased against migration, household income increases significantly. This is very much analogous to the expected line. Despite that, it 
is startling that the dynamic of power relations and attitude towards work in rural areas are not changing significantly despite so many government run schemes.

\section{Relative Importance}

The paper examines the relative importance of the chosen regressors by running a categorical regression. The results are as stated in Table 12. The sum of the weights $(w)$ is unity, out of which WID alone carries about 66 percent weight. This means that the monthly per capita household income increases significantly if women do engage in some gainful employment (Table 12). The correlation coefficient between PCI and WID is the highest in the entire correlation matrix. It is noticeable that GR which is defined as female-male ratio in a household has negative correlation with monthly household per capita income (PCI). However it is not significant. GR has also received the least importance as far as determining PCI of households. This observation has a substantial bearing on the traditional mindset that male is the 'bread earner' which has been an important basis of gender discrimination through centuries. These conclusions are in the line with changing perceptions towards gender in the modern perspective. The present study gives an empirical foundation to such perceptions.

Table 12: Correlations and Tolerance

\begin{tabular}{|l|c|c|c|c|c|c|}
\hline & \multicolumn{3}{|c|}{ Correlations } & Importance & \multicolumn{2}{c|}{ Tolerance } \\
\cline { 2 - 3 } & $\begin{array}{l}\text { Zero- } \\
\text { Order }\end{array}$ & Partial & Part & & $\begin{array}{c}\text { After } \\
\text { Transformation }\end{array}$ & $\begin{array}{c}\text { Before } \\
\text { Transformation }\end{array}$ \\
\hline AA & .164 & .191 & .153 & .067 & .955 & .927 \\
\hline WID & .508 & .523 & .482 & .657 & .953 & .917 \\
\hline GR & -.085 & -.084 & -.066 & .015 & .983 & .984 \\
\hline MGD & .219 & .258 & .210 & .123 & .959 & .959 \\
\hline WED & .257 & .152 & .121 & .086 & .900 & .806 \\
\hline AE & .200 & .118 & .093 & .052 & .894 & .745 \\
\hline $\begin{array}{l}\text { Dependent Variable: PCI } \\
\text { Note: Categorical regression is run by grouping method }\end{array}$ \\
\hline
\end{tabular}

\subsection{Summary and Main Findings}

The status of women is intimately connected with their economic status, which in turn, depends upon rights, roles and opportunity for the participation in economic activities. The governments across countries and states have also implemented a good number of schemes. However, question arises that, if implementation of all such schemes has brought a change in the ground reality? Is there any gender parity in economic participation especially in rural areas, where women have been historically 
voiceless? This paper attempted to investigate the crucial issue of gender aspect of livelihood and understand the role of gender in livelihood and family income. The analysis was structured on the basis of the following four research questions (hypotheses).

a) If gender has any role in occupation structure?,

b) If gender has any role in migration?

c) If gender has any role in the distribution of income of individuals?, and

d) If gender related variables play any significant role in determining the family income?

For an empirical analysis, the study took a case of a backward village from Bhadrak district of Odisha purposively, and did a census of all the 143 households. The main findings (Table 13) are as follows:

1. Neither a single house nor a single plot of land is registered in the name of women. In the absence of ownership, women as a lot are deprived from formal credit which necessitates mortgaging of some valued asset. This may be a reason why no formal credit, sans a few from the village SHG, was found in the name of any woman of the village. This is even more disappointing than the observation of Kelkar and Nathan (2005) that 'women own about 10 percent of assets in south Asia'. This is considered uneven considering women constitute about fifty percent of the population of the village.

2. The study finds a staggering reality that as many as 96 percent of rural women are willing to work in some gainful sectors along with their housekeeping but they are unable to get any opportunity. Poverty, lack of technical know-how, access to institutional credit, and marketing risks were cited reasons for non-initiating a venture at home. On enquiry regarding the opportunity provided by MNREGA, some of the respondents said it is difficult to work at distant from home that too for consecutive hours.

3. The work participation rate of women is very low. Out of 72 farmers, only one woman is a farmer. Similarly only one woman is doing labour work. Despite poverty, women do not like to work as labourers. Their families also consider it as an insult if women are required to work in others' field. Rather they prefer to accept poverty.

4. In case of male the highest number of people are engaged agriculture either as farmers or as agricultural labourers. Private non-manual job is also an important sector in the occupation structure of the village. About 26 percent workers are in private non-manual job. However, participation of women in any occupation is staggeringly low. 
Table 13: Main Findings of the Study

\begin{tabular}{|c|c|c|c|}
\hline $\begin{array}{l}\text { H. } \\
\text { No. }\end{array}$ & Null Hypothesis & Decision & Conclusion \\
\hline H1. & $\begin{array}{l}\text { The occupation } \\
\text { structure is independent } \\
\text { of gender }\end{array}$ & Rejected & $\begin{array}{l}\text { Participation in any occupation is gender- } \\
\text { biased. If the person is a women, she is } \\
\text { likely to be unemployed given the } \\
\text { conditions of the surveyed village }\end{array}$ \\
\hline $\mathrm{H} 2$ & $\begin{array}{l}\text { Migration is } \\
\text { independent of gender }\end{array}$ & Rejected & $\begin{array}{l}\text { Gender plays an important role in } \\
\text { migration. Rural women do not migrate for } \\
\text { any job. }\end{array}$ \\
\hline H3 & $\begin{array}{l}\text { The distribution of } \\
\text { income is same across } \\
\text { categories of gender }\end{array}$ & Rejected & $\begin{array}{l}\text { There exists severe skewness in the } \\
\text { distribution of income between men and } \\
\text { women of the village. Women get less } \\
\text { income due to less participation in the job } \\
\text { market }\end{array}$ \\
\hline $\mathrm{H} 4$ & $\begin{array}{l}\text { Gender related } \\
\text { variables play no role in } \\
\text { determining the family } \\
\text { income }\end{array}$ & Rejected & $\begin{array}{l}\text { Gender plays a significant role in raising } \\
\text { per capita income of households. If women } \\
\text { start earning, household income increases } \\
\text { significantly }\end{array}$ \\
\hline
\end{tabular}

\subsection{Policy Suggestions}

On the basis of the analysis, the study has the following suggestions.

a) In order to break the patriarchal form of gender relation, there is a need for change in the property inheritance so that gender access to assets can be fair.

b) Since women do not prefer migration and wage employment, efforts should be made to promote self-employment where men and women can complement and supplement one another. Self-employment sector survives and prospers only with proper skill development measures and market developments. Initiatives like Skill India Mission need to focus and specially target rural people especially women.

c) Women have very low access to institutional credit. Banks and other financial institutions cannot be compelled to extend loan to them due to their market considerations. However, there is a possible way out, that is, interest rate of loan from SHGs can be minimised so that micro enterprises through women entrepreneurship develops. 


\section{Endnotes}

1. DAY-NRLM stands for Deendayal Antyodaya Yojana-National Rural Livelihood Mission. This is the new incarnation of the NRLM whose genesis is in the erstwhile Swarnajayanti Swarozgar Yojana, 1999, a flagship programme of the Ministry of Rural Development, Government of India.

2. Child sex ratio is defined as the number of girls per 100 boys in the age group 0-6 year.

3. $\mathrm{MGD}=1$, if there is an out-migration by any adult family member, 0 ,-otherwise. So, only the code 3 for MGN in Table 1 is labeled as 1.

\section{References}

Agarwal, Bina (1994). A field of one's own: Gender and land rights in South Asia. Cambridge: Cambridge University Press.

Agarwal, Bina (2003). Women and land rights and the trap of neoconservatism. Journal of Agrarian Change 3(4): 571-85.

Chambers, Robert, \& Gordon Conway (1992). Sustainable rural livelihoods: Practical concepts for the 21st century. IDS Discussion Paper 296. Falmer: IDS.

DFID. (2009). Guidance note on gender mainstreaming and social exclusion in research. UK.

FAO. (2016). National gender profile of agricultural and rural livelihoods- Tajikistan, Food and Agriculture Organization of the United Nations, Ankara

Islam, Sirajul, \&Mahbuba Haque. (2007). Poverty reduction and empowerment of women through gender mainstreaming in development activities and microfinance: Some evidences from Asian experiences. Dhaka: INAFI Asia Trust.

Kabeer, Naila. (2007). Marriage, motherhood, masculinity in the global economy: Reconfiguration of personal and economic life, IDS Working Paper 296, Brighton: Pathways of Women's Empowerment and IDS. 
114 | PRAGATI: Journal of Indian Economy, Volume 3, Issue 2

Kelkar, Govind. (2005). Development effectiveness through gender mainstreaming: gender equality and poverty reduction in South Asia." Economic and Political Weekly, 40(44-45): 4690-4699.

Kelkar, Govind \& Dev Nathan. (2005). Gender, livelihoods and resources in south asia. Fifth South Asia Regional Ministerial Conference, Celebrating Beijing Plus Ten Islamabad. Pakistan.

Lopez, Augusto, \& Saadia Zahidi. (2005). Women's empowerment: measuring the global gender gap. Geneva: World Economic Forum.

UNRISD (2005). Gender equality: striving for justice in and unequal world- A policy report on gender and development 10 year after Beijing. Geneva: UNRISD.

World Bank. (2008). World development report: agriculture for development, Washington DC, World Bank 60.

World Bank, FAO and IFAD (2008). Gender in agriculture source book. Washington DC, World Bank. 